\title{
The effect of the renin-angiotensin-aldosterone system inhibition on myocardial function in early and late phases of dilated cardiomyopathy in $\operatorname{Tg} \alpha q^{*} 44$ mice
}

\author{
Mirosław Woźniak1, Urszula Tyrankiewicz², Łukasz Drelicharz¹, Tomasz Skórka², Magdalena Jabłońska², ${ }^{3}$, \\ Sylwia Heinze-Paluchowska ${ }^{2}$, Stefan Chłopicki ${ }^{1,4}$ \\ 'Department of Experimental Pharmacology, Chair of Pharmacology, Jagiellonian University Medical College, Krakow, Poland \\ 2Department of Magnetic Resonance Imaging, Institute of Nuclear Physics, Polish Academy of Sciences, Krakow, Poland \\ ${ }^{3}$ Department of Medical Physics and Biophysics, Faculty of Physics and Applied Computer Sciences, AGH University of Science \\ and Technology, Krakow, Poland \\ ${ }^{4}$ Jagiellonian Centre for Experimental Therapeutics (JCET), Jagiellonian University, Krakow, Poland
}

\begin{abstract}
Background: The renin-angiotensin-aldosterone system (RAAS) determines progression of heart failure (HF) in humans, and RAAS inhibition is a major therapeutic strategy in HF.

Aim: To assess the effect of angiotensin-converting enzyme inhibitor (ACE-I) and aldosterone receptor antagonist (ARA) therapy on the development of HF at its early and late stage in a murine model of dilated cardiomyopathy (Tg $\alpha q^{*} 44$ mice).

Methods: Tg $\alpha q^{*} 44$ mice at the early or advanced stage of HF received combined therapy including ACE-I (perindopril $2 \mathrm{mg} / \mathrm{kg}$ ) and ARA (canrenone $20 \mathrm{mg} / \mathrm{kg}$ ). Cardiac function was assessed by magnetic resonance imaging before and after 2 months of treatment.

Results: Combined therapy with perindopril and canrenone resulted in preserved systolic function at the early stage and reduced chamber dilatation at the advanced stage of HF in $\operatorname{Tg} \alpha q^{*} 44$ mice.

Conclusions: Activation of the RAAS is involved in progression of HF in Tg $\alpha q^{*} 44$ mice with dilated cardiomyopathy. Therapeutic efficacy of ACE-I and ARA to inhibit systolic dysfunction and cardiac chamber dilation depends on the stage of HF development. Key words: $\operatorname{Tg} \alpha \mathrm{q}^{*} 44$ mice, heart failure, magnetic resonance imaging, dobutamine, renin-angiotensin-aldosterone system, perindopril, canrenone
\end{abstract}

Kardiol Pol 2013; 71, 7: 730-737

\section{INTRODUCTION}

Activation of the renin-angiotensin-aldosterone system (RAAS) plays a major role in the development of heart failure (HF), and beneficial effects of RAAS inhibitors have been clearly established both in humans [1-3] and in experimental animal models of HF $[4,5]$. In the short-term, RAAS activation improves cardiac output by fluid and sodium retention, which increases the preload, but chronic RAAS activation leads to vasoconstriction, cardiovascular remodelling, and ultimately myocardial dysfunction. The RAAS is a compensatory mechanism but its overactivity (in response to factors increasing myocardial load, e.g. hypertension or myocardial ischaemia) along with activation of other neurohormonal systems (e.g. sympathetic nervous system) leads to myocardial dysfunction and development of HF [6].

Both angiotensin II and aldosterone contribute to HF progression by inducing myocardial hypertrophy and remodelling, activating fibrosis (i.e. collagen synthesis and deposition)

\section{Address for correspondence:}

Prof. Stefan Chłopicki, Jagiellonian Centre for Experimental Therapeutics (JCET), ul. Bobrzyńskiego 14, 30-348 Kraków, Poland, tel: +48 122974617,

e-mail: stefan.chlopicki@jcet.eu

Received: 28.06.2012 Accepted: 27.02.2013

Copyright (C) Polskie Towarzystwo Kardiologiczne 
and apoptosis, and inducing endothelial dysfunction which is associated with increased synthesis of superoxide anions $\left(\mathrm{O}_{2}^{-}\right)$, endothelin- 1 and plasminogen activator inhibitor- 1 , and decreased synthesis of vasoprotective nitric oxide (NO) and other alterations. Both inhibition of angiotensin-converting enzyme (ACE) by ACE inhibitors (ACE-I) and the use of angiotensin $\mathrm{AT}_{1}$ receptor antagonists and aldosterone receptor antagonists (ARA) are effective in the treatment of HF [7], although debate continues regarding the optimal approach for combined RAAS inhibition in HF with reduced or preserved systolic function, fuelled by emerging data from both clinical and experimental studies.

A model of dilated cardiomyopathy in Tg $\alpha q^{*} 44$ mice is particularly interesting in this regard, as the observed HF phenotype is the result of overexpression of active G $\alpha q$ subunit in cardiomyocytes, imitating at the level of cardiomyocytes continuous overactivation of angiotensin II, endothelin-1, and noradrenaline receptors [8] characteristic for increased RAAS activity. Thus, the HF phenotype in Tg $\alpha q^{*} 44$ mice imitates the pathophysiology of HF in humans at the molecular, biochemical, and functional level [6, 8-12]. G $\alpha q^{*}$ expression in Tg $\alpha q^{*} 44$ mice is reduced as compared to Tg $\alpha q^{*} 52$ mice, resulting in a relatively lower rate of disease progression which allows progressive changes to be observed and identified [8].

Cardiomyocyte hypertrophy, myocardial fibrosis, and foetal cardiomyocyte phenotype are clearly seen already in 4-month-old $\operatorname{Tg} \alpha q^{*} 44$ mice but evident reduction in ejection fraction and impairment of systolic-diastolic dynamics occur not earlier than in 12-month old Tg $\alpha$ q*44 mice, accompanied by a gradual increase in mortality [1]. Presumably, chronic compensated HF in this model depends on activation of multiple neurohormonal systems, including compensatory RAAS activation which also contributes with time to the progression of HF in Tg $\alpha q^{*} 44$ mice. It is not known, however, to what extent the development of HF in the Tg $\alpha q^{*} 44$ mice model depends on secondary RAAS activation, and whether there is any association between RAAS activation and disease progression. Perhaps overexpression of continuously active $\mathrm{G} \alpha \mathrm{q}$ subunit in cardiomyocytes may itself result in the development of HF. To examine the pathologic role of secondary RAAS activation in the development of HF in Tg $\alpha q^{*} 44$ mice, we evaluated the therapeutic efficacy of RAAS blockade to inhibit the development of HF at early and late phases of dilated cardiomyopathy in $\operatorname{Tg} \alpha q^{*} 44$ mice.

\section{METHODS}

\section{Experimental protocol}

In this study, $\operatorname{Tg} \alpha \mathrm{q}^{*} 44$ female mice were used at the early and late stage of heart failure (12- and 15-month-old, respectively) [10]. Tg $\alpha q^{*} 44$ mice were previously characterised by Mende et al. [8]. Tg $\alpha q^{*} 44$ mice used in the current experiment were bred at the Institute of Experimental and Clinical Medicine at the Polish Academy of Sciences in Warsaw. Prior to the ex- periments, the animals were transported to the animal house at the Institute of Nuclear Physics in Krakow and kept under constant conditions of $12 / 12$ light cycle, humidity of $60 \%$ and temperature of about $23^{\circ} \mathrm{C}$, with uninterrupted access to food and water. The study was approved by a local bioethics committee in Krakow (approval No. 470/2007).

The severity of HF was evaluated based on global impairment of cardiac function as determined by fractional area change (FAC) [\%] and compared to control FVB mice [10]. As FAC decreases with time in untreated HF, we used 12- and 15-month-old Tg $\alpha q^{*} 44$ mice, the latter being characterised by significantly lower FAC compared to 12-month-old animals $(p<0.05)$. Treatment was based on ACE-I perindopril (Prestarium, Servier) and ARA canrenone (Sigma-Aldrich) ( $n=17$, including 6 treated and 11 control mice with early $\mathrm{HF}$; and $\mathrm{n}=26$, including 13 treated and 13 control mice with late HF). Drugs were administered with drinking water for 2 months at $2 \mathrm{mg} / \mathrm{kg}$ (perindopril) and $20 \mathrm{mg} / \mathrm{kg}$ (canrenone). After therapy, the number of animals in all groups decreased due to mortality (early HF: 5 treated and 8 control mice; late HF: 7 treated and 5 control mice, including 5 treated and 4 control mice which underwent dobutamine testing). Animals were randomly assigned to study groups after initial in vivo functional evaluation. Relatively low numbers of animals with early HF precluded evaluation of the effect of therapy on mortality, and our analysis was restricted to the effect of therapy on functional cardiac parameters.

\section{In vivo cardiac MRI}

Left ventricular (LV) function was evaluated before and after therapy using magnetic resonance imaging (MRI).

For the measurements we used dedicated small animal MRI system consisting of 4.7 T magnet (Bruker, Germany), MARAN DRX console (Resonance Instruments, Great Britain), and a home-built probehead containing gradient coils (ID $60 \mathrm{~mm}, 500 \mathrm{mT} / \mathrm{m} / 100 \mathrm{~A}$ ) and a radiofrequency birdcage coil [13].

Mice were anesthetised with $2 \%$ isoflurane in oxygen and air mixture (40:60\%) delivered through a nose cone and placed in the supine position in the magnet centre with the use of the animal bed. ECG was registered and temperature was monitored and stabilised at $35^{\circ} \mathrm{C}$ (S.A. Instruments Inc., USA) during entire MRI examination.

LV function was assessed from images collected in a short-axis view at the papillary muscle level using an ECG-gated fast gradient echo sequence (cine-FLASH) as described previously (slice thickness $1.5 \mathrm{~mm}$, field of view $30 \times 30 \mathrm{~mm}^{2}$, matrix size $128 \times 128$, echo time $2.5 \mathrm{~ms}$, repetition time depending on the cardiac cycle length and the number of images per cycle) [10].

In the late HF group, additional dobutamine stress test was performend for the assessment of cardiac reserve. Cardiac functional reserve was assessed by intraperitoneal administra- 


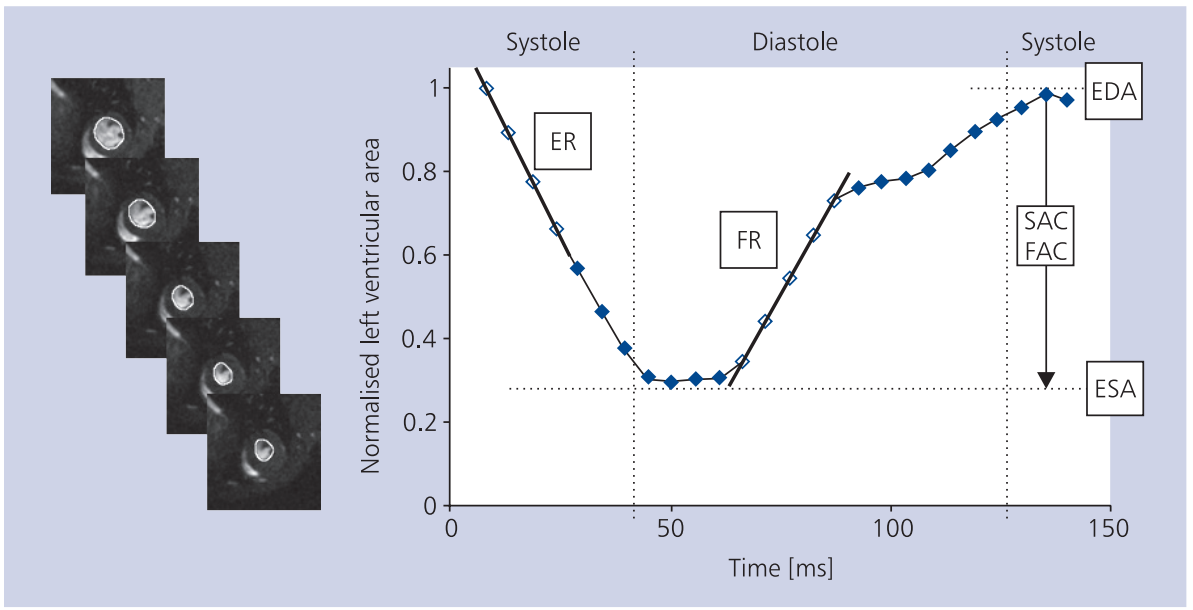

Figure 1. Sample images and segmentation of the cross-sectional view of murine myocardium at the level of papillary muscles (areas normalised for the end-diastolic area). Parameters: ejection ratio (ER) - systolic dynamics; filling ratio (FR) - diastolic dynamics measured at early ventricular filling; end-systolic area (ESA) - end-systolic left ventricular area; end-diastolic area (EDA) — end-diastolic left ventricular area; fractional area change $(F A C)=(E D A-E S A) / E D A ;$ stroke area change $(S A C)=E D A-E S A$

Table 1. Myocardial function parameters in $\operatorname{Tg} \alpha q^{*} 44$ mice at an early stage of heart failure (12-14 months of age). Combined treatment with canrenone $(20 \mathrm{mg} / \mathrm{kg}$ ) and perindopril $(2 \mathrm{mg} / \mathrm{kg}$ ) was administered for 2 months. Significant left ventricular dysfunction can be noted in the control (untreated) group, as manifested by a decrease in FAC and SAC and an increase in ESA. No further impairment of myocardial function was seen in the treated group

\begin{tabular}{lccc} 
Parameter & Before therapy & \multicolumn{2}{c}{ After therapy } \\
\cline { 2 - 4 } & & $\mathrm{N}=8 / 11$ & Treatment \\
\hline No. of animals & $\mathrm{N}=17$ & $55.0 \pm 6.3^{*}$ & $\mathrm{~N}=5 / 6$ \\
FAC [\%] & $69.6 \pm 11.7$ & $7.6 \pm 1.3^{*}$ & $60.5 \pm 9.8$ \\
ESA [mm²] & $5.2 \pm 1.7$ & $17.0 \pm 2.6$ & $7.1 \pm 3.1$ \\
EDA $\left[\mathrm{mm}^{2}\right]$ & $17.5 \pm 2.6$ & $9.4 \pm 2.1^{*}$ & $17.1 \pm 5.3$ \\
SAC $\left[\mathrm{mm}^{2}\right]$ & $12.0 \pm 2.9$ & $0.0150 \pm 0.0054$ & $10.0 \pm 2.5$ \\
ER [EDA/ms] & $0.0143 \pm 0.0046$ & $0.0152 \pm 0.0054$ & $0.0136 \pm 0.0061$ \\
FR [EDA/ms] & $0.0216 \pm 0.0084$ & $0.0197 \pm 0.0082$
\end{tabular}

${ }^{*} p<0.05$ for comparison of values after and before therapy. Mean values \pm standard deviation are shown. Abbreviations see text and Figure 1.

tion of dobutamine at $1.5 \mathrm{mg} / \mathrm{kg}$ dissolved in $200 \mu \mathrm{L}$ of saline (Dobutamine-Hexal, Sandoz, Germany). Dobutamine was administered immediately after collection of basal images. Then, the cardiac function was measured twice after $8 \mathrm{~min}$ and $12 \mathrm{~min}$, corresponding to the most pronounced chronotropic response (for further analyses, we used data showing the strongest inotropic response). Changes in the area of a defined LV slice during the cardiac cycle were evaluated based on the analysis of at least 20 images.

\section{Data analysis and statistical analysis}

Images were segmented using dedicated Aphelion macros (ADCIS, France) [14]. Based on the obtained images and LV time-area curve, following parameters of cardiac function were assessed: end-diastolic area (EDA), end-systolic area (ESA), ejection ratio (ER) and filling ratio (FR) (Fig. 1).
Stroke area change (SAC) was calculated as the difference between EDA and ESA. Heart rate (HR) was the mean value during monitoring of the animal throughout anaesthesia. All parameters were assessed before and after 2 months of experiment in each study group, what allowed for monitoring cardiac functional changes during development of pathology. Measurements in the control groups gave information on the natural progression of HF in the studied model.

Statistical analyses were performed using STATISTICA (StatSoft Inc., USA) and MS Excel (Microsoft, USA). Results are shown as mean \pm SD (Tables 1,2$)$ or as percentage changes of a given parameter (Figs. 2, 3). Differences between groups were compared using the Student t test for normally distributed data or the Mann-Whitney $U$ test for non-normally distributed data. The normality of data distribution was verified using the Shapiro-Wilk test, and variance homogeneity 
Table 2. Myocardial function parameters in Tg $\alpha q^{*} 44$ mice at the end-stage of heart failure (15-17 months of age). Combined treatment with canrenone $(20 \mathrm{mg} / \mathrm{kg}$ ) and perindopril $(2 \mathrm{mg} / \mathrm{kg}$ ) was administered for 2 months. Table shows values at resting conditions and after beta-adrenergic stimulation using dobutamine. In the treated group, no significant changes in basal myocardial function can be seen, along with improvement of myocardial reserve in response to dobutamine. No changes indicating myocardial remodelling and chamber dilatation (EDA, ESA) can be seen in the treated group, in contrast to the untreated group

\begin{tabular}{|c|c|c|c|c|c|c|}
\hline \multirow[t]{3}{*}{ Parameter } & \multicolumn{2}{|c|}{ Before therapy } & \multicolumn{4}{|c|}{ After therapy } \\
\hline & \multirow[b]{2}{*}{$\begin{array}{c}\text { Resting } \\
\text { conditions }\end{array}$} & \multirow[b]{2}{*}{$\begin{array}{c}\text { After } \\
\text { dobutamine } \\
\text { stimulation }\end{array}$} & \multicolumn{2}{|c|}{ Placebo } & \multicolumn{2}{|c|}{ Treatment } \\
\hline & & & $\begin{array}{c}\text { Resting } \\
\text { conditions }\end{array}$ & $\begin{array}{c}\text { After } \\
\text { dobutamine } \\
\text { stimulation }\end{array}$ & $\begin{array}{c}\text { Resting } \\
\text { conditions }\end{array}$ & $\begin{array}{c}\text { After } \\
\text { dobutamine } \\
\text { stimulation }\end{array}$ \\
\hline $\begin{array}{l}\text { No. of } \\
\text { animals }\end{array}$ & $N=26$ & $N=22 / 26$ & $N=5 / 13$ & $N=4 / 5$ & $N=7 / 13$ & $N=5 / 7$ \\
\hline FAC [\%] & $52.4 \pm 11.1$ & $59.6 \pm 13.0 \#$ & $52.8 \pm 11.5$ & $53.0 \pm 13.6$ & $51.8 \pm 5.6$ & $58.8 \pm 8.6$ \\
\hline $\mathrm{ESA}\left[\mathrm{mm}^{2}\right]$ & $7.1 \pm 2.4$ & $6.9 \pm 2.6 \#$ & $9.5 \pm 4.1$ & $9.7 \pm 4.2$ & $7.6 \pm 2.8$ & $7.2 \pm 2.6 \#$ \\
\hline $\mathrm{EDA}\left[\mathrm{mm}^{2}\right]$ & $14.5 \pm 2.8$ & $14.0 \pm 3.7$ & $19.1 \pm 5.3$ & $20.1 \pm 3.9$ & $15.6 \pm 4.5$ & $17.3 \pm 4.3$ \\
\hline $\mathrm{SAC}\left[\mathrm{mm}^{2}\right]$ & $7.5 \pm 1.6$ & $8.0 \pm 2.5$ & $9.7 \pm 1.8^{*}$ & $10.3 \pm 1.8$ & $7.9 \pm 2.0$ & $10.1 \pm 2.7$ \\
\hline ER [EDA/ms] & $0.0131 \pm 0.0040$ & $0.0163 \pm 0.0045 \#$ & $0.0145 \pm 0.0088$ & $0.0119 \pm 0.0042$ & $0.0117 \pm 0.0014$ & $0.0143 \pm 0.0020 \#$ \\
\hline FR [EDA/ms] & $0.0129 \pm 0.0067$ & $0.0136 \pm 0.0061$ & $0.0117 \pm 0.0025$ & $0.0131 \pm 0.0051$ & $0.0061 \pm 0.0012^{*}$ & $0.0116 \pm 0.0039$ \\
\hline
\end{tabular}

${ }^{*} p<0.05$ for comparison of values after and before therapy; $\# p<0.05$ for comparison of values at resting conditions and after dobutamine stimulation. Mean values \pm standard deviation are shown. Abbreviations see text and Figure 1.

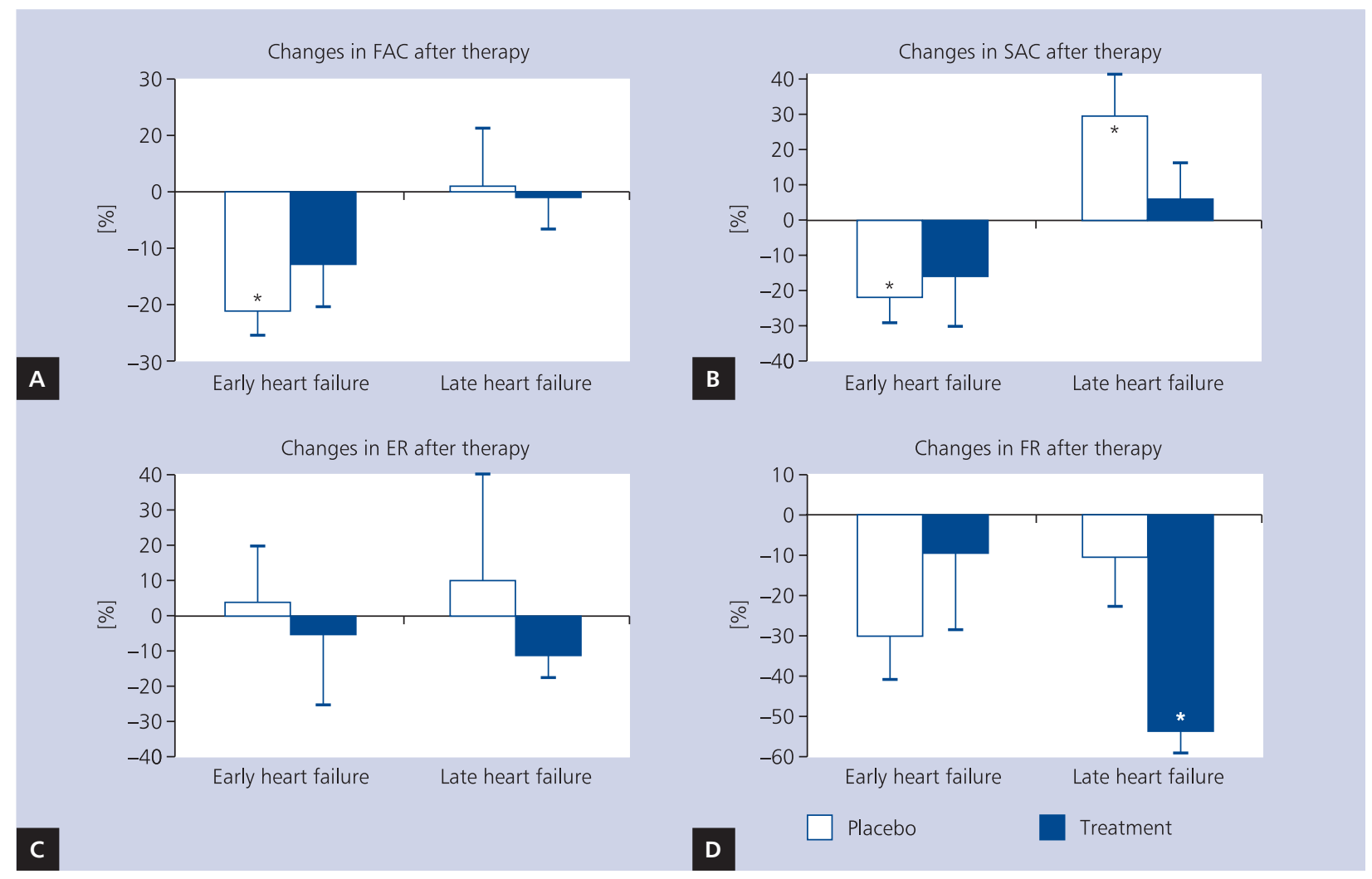

Figure 2. Changes in resting myocardial function. A. Fractional area change (FAC); B. Stroke area change (SAC); C. Ejection ratio (ER); D. Filling ratio (FR) after 2 months of combined treatment with canrenone and perindopril in Tg $\alpha q^{*} 44$ mice at the early or late stage of heart failure. Combined treatment reduced impairment of FAC and SAC noted in the control group, but only in early heart failure. In late heart failure, the treatment reduced SAC deterioration and significantly attenuated resting diastolic dynamics; ${ }^{*} p<0.05$ for comparison of values after and before therapy 


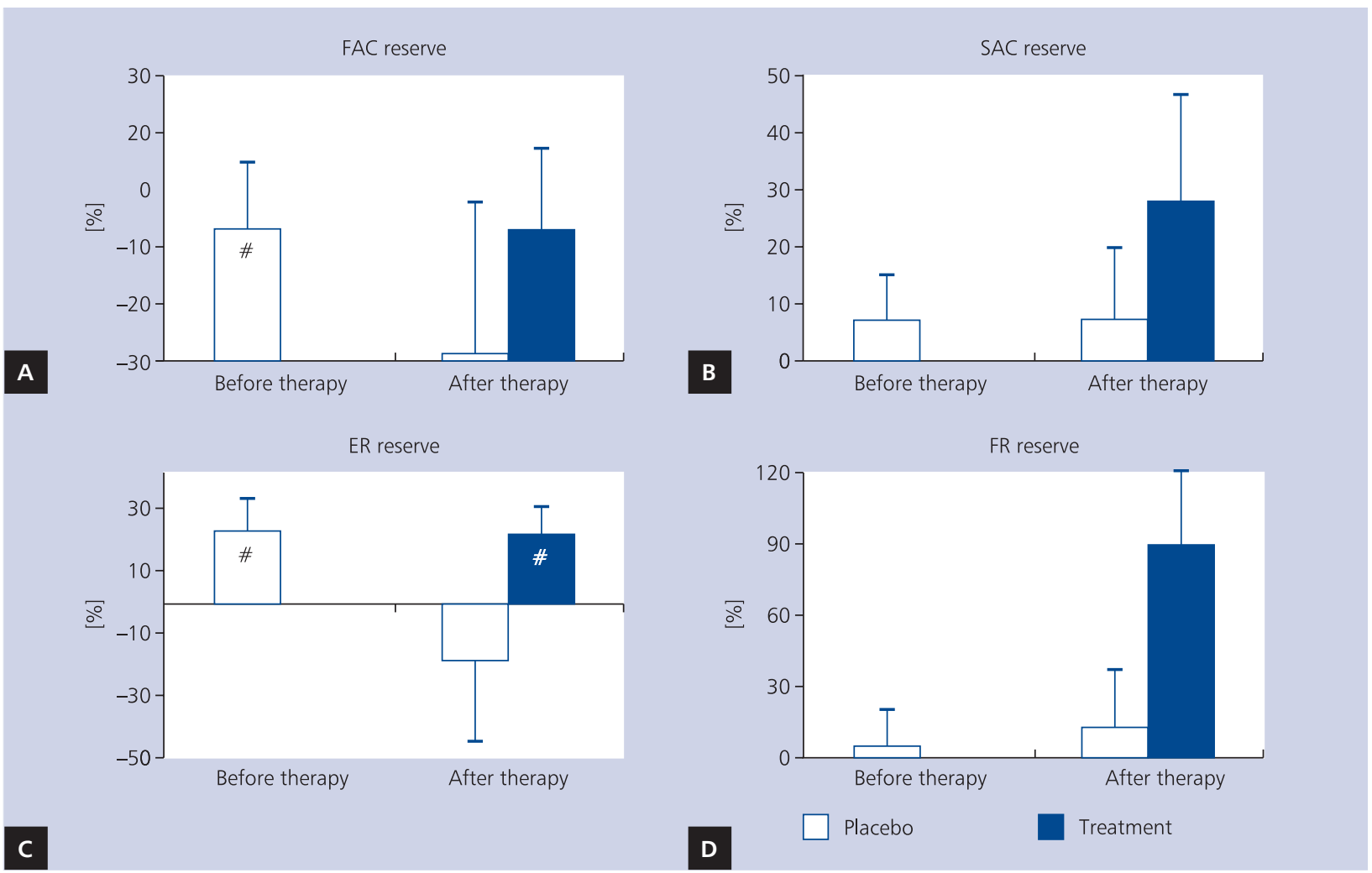

Figure 3. Myocardial function reserve in $\operatorname{Tg} \alpha \mathrm{q}^{*} 44$ mice at the late stage of heart failure. Combined treatment was associated with the preservation of FAC (A), SAC (B), ER (C), and FR (D) reserve; $\# p<0.05$ for comparison of values at resting conditions and after dobutamine stimulation; abbreviations as in Figure 2

was evaluated using the Brown-Forsythe test. $\mathrm{P}<0.05$ was considered statistically significant.

\section{RESULTS}

\section{Changes in cardiac function in the early phase} of heart failure in $\mathrm{Tg} \alpha q^{*} 44$ mice

Table 1 and Figure 2 show LV functional parameters in the early phase of $\mathrm{HF}$ development in $\operatorname{Tg} \alpha \mathrm{q}^{*} 44$ mice before and after treatment. Progressive impairment of FAC and SAC and an increase in ESA were noted in untreated animals (12- to 14-month-old Tg $\alpha q^{*} 44$ mice), while FAC and SAC impairment was attenuated in the treated group. No changes in systolic-diastolic dynamics (ER-FR) were seen both in response to HF progression and the therapy used, although the decrease in filling dynamics seemed to be slightly lower in the treated group.

\section{Changes in cardiac function in the late phase of heart failure in Tgaq*44 mice}

Table 2 shows myocardial function parameters in the late phase of HF development in Tg $\alpha q^{*} 44$ mice before and after 2-month treatment (15- to 17-month-old Tg $\alpha q^{*} 44$ mice) with canrenone and perindopril, evaluated at rest and after dobutamine stimulation in comparison to the untreated group. Dur- ing development of untreated $\mathrm{HF}$, only a significant increase in SAC was noted without changes in any other functional parameters. In the treated group, dynamics of LV filling (FR) was more impaired compared to the untreated group, but the therapy did not affect SAC and other functional parameters at resting conditions.

Dobutamine stimulation (before animal assignment to the control and treated groups) resulted in a significant increase in FAC and ER, a decrease in ESA, and a slight increase in FR. In the untreated group, an impairment of systolic reserve (ER change) was noted, while diastolic reserve (FR change) remained unchanged. After 2 months of treatment, systolic reserve was preserved and diastolic reserve was increased as compared to untreated Tg $\alpha q^{*} 44$ mice.

\section{DISCUSSION}

Our study showed that RAAS inhibition with ACE-I (perindopril) and ARA (canrenone) at the early stage of HF development in Tg $\alpha q^{*} 44$ mice attenuated LV dysfunction and progression of HF. RAAS inhibition at the later stage of HF development had lesser therapeutic effects on myocardial function at rest but attenuated the development of ventricular dilatation and was associated with lesser impairment of functional systolic and diastolic reserve in Tg $\alpha q^{*} 44$ mice. Both in 
the early and the late phases of HF development, RAAS inhibition reduced HF progression similarly to the clinical effects observed in patients with HF. These data suggest that RAAS overactivity is responsible for HF progression in Tg $\alpha q^{*} 44$ mice, similarly to HF in humans. Thus, it seems that Tg $\alpha q^{*} 44$ mice represent a relevant model of HF progression to study both molecular mechanisms underlying cardiac decompensation and the efficacy of new therapies.

\section{Heart failure progression in Tg $\alpha q^{*} 44$ mice}

Development of myocardial dysfunction at the early stage of HF development (in 12-month-old Tg $\alpha q^{*} 44$ mice) is characterised by impaired systolic function (decrease in FAC and SAC and increase in ESA, Table 1, Fig. 2). At a more advanced stage of $\mathrm{HF}$ development, impaired LV function (FAC) in 15-month-old Tg $\alpha q^{*} 44$ mice is similar but a significant compensatory LV dilatation (as manifested by increased ESA and EDA) develops to maintain adequate stroke volume. At this stage of HF development, myocardial functional reserve is also significantly impaired. These changes seem to be similar to those reported during the development of dilated cardiomyopathy in humans.

\section{Effect of RAAS inhibition on cardiac function in $\operatorname{Tg} \alpha{ }^{*} 44$ mice}

Inhibition of RAAS overactivity at the early stage of HF development in $\operatorname{Tg} \alpha q^{*} 44$ mice using ACE-I (perindopril) and ARA (canrenone) resulted in a significant attenuation of HF progression. In the treated group, LV function impairment (as measured by FAC and SAC, Fig. 2A, C) was reduced as compared to the untreated animals. At the later stage of HF development in Tg $\alpha q^{*} 44$ mice, RAAS inhibition with perindopril and canrenone had lesser effect on resting myocardial function (a beneficial effect was only seen on SAC) but attenuated LV remodelling (reduced ventricular dilatation, Table 2) and, importantly, preserved myocardial functional reserve (particularly diastolic reserve) in response to beta-adrenergic stimulation (Table 2, Fig. 3). In this context, a large reduction of diastolic dynamics (FR) observed in Tg $\alpha q^{*} 44$ mice in resting conditions may be an important compensatory response that allows maintaining diastolic reserve in advanced $\mathrm{HF}$.

Both in early and late phases of HF development in Tg $\alpha q^{*} 44$ mice, RAAS inhibition decreased progression of HF mostly by reducing systolic dysfunction (as evidenced by measurements of LV ejection fraction or stroke volume) and attenuating the development of cardiac chamber dilatation.

Development of HF in $\mathrm{Tg} \alpha \mathrm{q} * 44$ mice results both from G $\alpha$ q overexpression in cardiomyocytes and secondary changes induced by underlying cardiac pathology. In fact myocardial remodelling and cardiomyocyte hypertrophy result from $\mathrm{G} \alpha \mathrm{q}$ overexpression [15]. However, myocardial fibrosis seen in Tg $\alpha q^{*} 44$ mice already at the age of 4 months [6] seems not to result solely from $\mathrm{G} \alpha \mathrm{q}$ overexpression in cardiomyocytes. Similarly, development of coronary endothelial dysfunction [9] that includes decreased $\mathrm{NO}$ synthesis and increased production of free oxygen species, is not a direct effect of G $\alpha$ q overexpression in cardiomyocytes but rather results from secondary RAAS activation, and in particular might be mediated by aldosterone [16]. Finally, myocardial dysfunction and impairment of functional reserve seen in late HF depend to some extent on secondary RAAS activation, as evidenced by our findings of beneficial effects of RAAS inhibitors to attenuated HF progression in this model. Detailed investigation as regard to the activation of compensatory mechanisms and their effects on cardiac functional changes seems crucial for understanding the mechanisms of progresivelly developing HF in Tg $\alpha q^{*} 44$ mice as well as to examinate effectivness of novel therapies.

\section{Limitations of the study}

Due to advanced HF in Tg $\alpha q^{*} 44$ mice, we observed significant mortality during experiments. Furthermore, low numbers of animals in the study groups precluded evaluation of the effect of therapy on mortality. In addition, we observed a large variability of resting myocardial function parameters in $\operatorname{Tg} \alpha q^{*} 44$ mice at the same age before treatment initiation. This observation may reflect individual differences in progression of dilated cardiomyopathy. In our study, we evaluated the effect of RAAS inhibition on myocardial function in $\operatorname{Tg} \alpha q^{*} 44$ mice using MRI in vivo, and we did not analyse the effects of therapy on histological, biochemical, and molecular characteristics of the failing myocardium.

\section{CONCLUSIONS}

In summary, our findings indicate a key role of the RAAS in the progression of $\mathrm{HF}$ in dilated cardiomyopathy in Tg $\alpha \mathrm{q}^{*} 44$ mice. Apparently, the overexpression of active G $\alpha q$ in cardiomyocytes leads with time to the activation of RAAS that drives the pathology development. Our results also indicate that at the early stage of HF, RAAS inhibition improves resting myocardial function, while the beneficial cardiac effects of RAAS inhibition at the later stage of HF are mostly related to attenuation of LV remodelling and preservation of functional reserve, without any significant effects on myocardial function parameters at rest.

This work was supported by the European Union from the resources of the European Regional Development Fund under the Innovative Economy Programme (grant coordinated by JCET-UJ, No POIG.01.01.02-00-069/09).

Conflict of interest: none declared 


\section{References}

1. Flather MD, Yusuf S, Kober L et al. Long-term ACE-inhibitor therapy in patients with heart failure or left-ventricular dysfunction: a systematic overview of data from individual patients. ACE-Inhibitor Myocardial Infarction Collaborative Group. Lancet, 2000; 355:1575-1581.

2. McMurray JJ, Pfeffer MA, Swedberg K, Dzau VJ. Which inhibitor of the renin-angiotensin system should be used in chronic heart failure and acute myocardial infarction? Circulation, 2004; 110: 3281-3288.

3. Latini R, Tognoni G, Maggioni AP et al. Clinical effects of early angiotensin-converting enzyme inhibitor treatment for acute myocardial infarction are similar in the presence and absence of aspirin: systematic overview of individual data from 96,712 randomized patients. Angiotensin-converting Enzyme Inhibitor Myocardial Infarction Collaborative Group. J Am Coll Cardiol, 2000; 35: 1801-1807.

4. Silvestre JS, Heymes C, Oubenaissa A et al. Activation of cardiac aldosterone production in rat myocardial infarction: effect of angiotensin II receptor blockade and role in cardiac fibrosis. Circulation, 1999; 99: 2694-2701.

5. Yoshiyama M, Nakamura Y, Omura T et al. Angiotensin converting enzyme inhibitor prevents left ventricular remodelling after myocardial infarction in angiotensin II type 1 receptor knockout mice. Heart, 2005; 91: 1080-1085.

6. Mackiewicz U, Czarnowska E, Brudek M et al. Preserved cardiomyocyte function and altered desmin pattern in transgenic mouse model of dilated cardiomyopathy. J Mol Cell Cardiol, 2012; 52: 978-987.

7. Dickstein K, Cohen-Solal A, Filippatos G et al. ESC guidelines for the diagnosis and treatment of acute and chronic heart failure 2008: the Task Force for the diagnosis and treatment of acute and chronic heart failure 2008 of the European Society of Cardiology. Developed in collaboration with the Heart Failure Association of the ESC (HFA) and endorsed by the European Society of Intensive Care Medicine (ESICM). Eur J Heart Fail, 2008; 10: 933-989.

8. Mende U, Semsarian C, Martins DC et al. Dilated cardiomyopathy in two transgenic mouse lines expressing activated $\mathrm{G}$ protein alpha(q): lack of correlation between phospholipase $\mathrm{C}$ activation and the phenotype. J Mol Cell Cardiol, 2001; 33: 1477-1491.

9. Drelicharz L, Kozlovski V, Skorka T et al. NO and PGI(2) in coronary endothelial dysfunction in transgenic mice with dilated cardiomyopathy. Basic Res Cardiol, 2008; 103: 417-430.

10. Drelicharz L, Wozniak M, Skorka T et al. Application of magnetic resonance imaging in vivo for the assessment of the progression of systolic and diastolic dysfunction in a mouse model of dilated cardiomyopathy. Kardiol Pol, 2009; 67: 386-395.

11. Mende U, Kagen A, Cohen A et al. Transient cardiac expression of constitutively active Galphaq leads to hypertrophy and dilated cardiomyopathy by calcineurin-dependent and independent pathways. Proc Natl Acad Sci USA, 1998; 95: 13893-13898.

12. Elas M, Bielanska J, Pustelny K et al. Detection of mitochondrial dysfunction by EPR technique in mouse model of dilated cardiomyopathy. Free Radic Biol Med, 2008; 45: 321-328.

13. Heinze-Paluchowska S, Skorka T, Drelicharz L et al. MR imaging of mouse heart in vivo using a specialized probehead and gradient system. Pol J Chem, 2006; 80: 1133.

14. Kosecka S, Wojnar L, Petryniak R et al. Application of image analysis for quantification of cardiac function in vivo by MRI in the mouse model of heart failure. Inzynieria Materiałowa, 2008; 29: 459-462.

15. D’Angelo DD, Sakata Y, Lorenz JN et al. Transgenic Galphaq overexpression induces cardiac contractile failure in mice. Proc Natl Acad Sci USA, 1997; 94: 8121-8126.

16. Heymes C, Garnier A, Fuchs S et al. Aldosterone-synthase overexpression in heart: a tool to explore aldosterone's effects. Mol Cell Endocrinol, 2004; 217: 213-219. 


\title{
Wpływ zahamowania układu renina-angiotensyna- -aldosteron na czynność mięśnia sercowego we wczesnym i późnym etapie rozwoju kardiomiopatii rozstrzeniowej u myszy $\operatorname{Tg} \alpha q^{*} 44$
}

\author{
Mirosław Woźniak ${ }^{1}$, Urszula Tyrankiewicz² , Łukasz Drelicharz ${ }^{1}$, Tomasz Skórka², Magdalena Jabłońska², 3 , \\ Sylwia Heinze-Paluchowska ${ }^{2}$, Stefan Chłopicki ${ }^{1,4}$ \\ 'Zakład Farmakologii Doświadczalnej, Katedra Farmakologii, Collegium Medicum, Uniwersytet Jagielloński, Kraków \\ 2Zakład Tomografii Magnetyczno-Rezonansowej, Instytut Fizyki Jądrowej, Polska Akademia Nauk, Kraków \\ ${ }^{3}$ Katedra Fizyki Medycznej i Biofizyki, Wydział Fizyki i Informatyki Stosowanej, Akademia Górniczo-Hutnicza, Kraków \\ 4Jagiellońskie Centrum Rozwoju Leków (JCET), Uniwersytet Jagielloński, Kraków
}

\section{Streszczenie}

Wstęp: Aktywacja układu renina-angiotensyna-aldosteron (RAA) determinuje progresję niewydolności serca (HF) u ludzi, a zahamowanie układu RAA stanowi podstawę leczenia HF u pacjentów z obniżoną frakcją wyrzutową.

Cel: Celem pracy była ocena skuteczności terapeutycznej inhibitorów układu RAA we wczesnym i późnym etapie rozwoju HF w mysim modelu kardiomiopatii rozstrzeniowej (myszy Tg $\left.\alpha q^{*} 44\right)$ ).

Metody: Myszy Tg $\alpha q^{*} 44$ zostały poddane terapii łączonej: kanrenonem (20 mg/kg) i perindoprilem (2 mg/kg) we wczesnej oraz późnej fazie HF. Czynność mięśnia sercowego oceniano metodą obrazowania magnetyczno-rezonansowego przed 2-miesięczną terapią oraz po jej zakończeniu.

Wyniki: Terapia skojarzona (perindopril + kanrenon) zastosowana u myszy Tg $\alpha q^{*} 44$ we wczesnej fazie HF pozwoliła ograniczyć upośledzenie czynności skurczowej mięśnia sercowego, podczas gdy na późnym etapie hamowała rozwój rozstrzeni. Wnioski: Ograniczenie rozwoju HF w modelu Tg $\alpha$ q*44 zarówno na wczesnym, jak i późnym etapie HF poprzez hamowanie układu RAA przy użyciu perindoprilu i kanrenonu wskazuje na udział układu RAA w rozwoju HF u myszy Tg $\alpha q^{*} 44$ analogicznie do patologicznej roli układu RAA u ludzi z HF. Skuteczność terapeutyczna inhibitorów układu RAA w ograniczaniu upośledzenia czynności skurczowej i rozstrzeni zależy od stopnia progresji dekompensacji mięśnia sercowego.

Słowa kluczowe: myszy Tg $\alpha$ q*44, niewydolność serca, obrazowanie magnetyczno-rezonansowe, dobutamina, układ RAA, perindopril, kanrenon

Kardiol Pol 2013; 71, 7: 730-737

\section{Adres do korespondencji:}

prof. dr hab. n. med. Stefan Chłopicki, Jagiellońskie Centrum Rozwoju Leków, Uniwersytet Jagielloński, ul. Bobrzyńskiego 14, 30-348 Kraków, tel: +48 12 2974617, e-mail: stefan.chlopicki@jcet.eu 